\title{
Evaluation of different methods for preventing the African swine fever virus
}

\author{
Simona Pilevičienè ${ }^{1,2^{*}}$, \\ Vaclovas Jurgelevičius ${ }^{1,2}$, \\ Žygimantas Janeliūnas ${ }^{1,2}$, \\ Gediminas Pridotkas ${ }^{1}$, \\ Petras Mačiulskis ${ }^{1}$, \\ Ričardas Krikštolaitis ${ }^{2}$, \\ Algimantas Paulauskas $^{2}$ \\ ${ }^{1}$ National Food and Veterinary \\ Risk Assessment Institute, \\ J. Kairiūkščio 10, Vilnius 08409, Lithuania \\ ${ }^{2}$ Vytautas Magnus University, \\ K. Donelaičio g. 58, \\ Kaunas 44248, Lithuania
}

\begin{abstract}
African swine fever (ASF) is a contagious disease of key importance that occurs in wild boar population and domestic pigs. To date, there is no vaccine or treatment available, hence disease surveillance and stamping out in case of an outbreak is the only way to control it. A duplex ASF-IC real-time PCR assay was optimised using field samples obtained in Lithuania and results of singleplex and duplex real-time PCR assays allowing the identification of the ASF virus were compared. The specificity and sensitivity of ASF virus detection was validated using a reference sample of positive and negative virus nucleic acid and ASF virus positive and negative samples obtained from animals in Lithuania. Results prove that duplex ASF-IC real-time PCR assay provides a rapid, sensitive, and reliable molecular tool for ASF virus detection in wild boar population and domestic pigs. In general, it was found that duplex ASF-IC real-time PCR assay proves to be faster and more sensitive than singleplex real-time PCR and therefore has a high potential to be applied in routine analysis.
\end{abstract}

Keywords: African swine fever virus detection, domestic pigs, duplex real-time PCR assays, singleplex real-time PCR assays, wild boar

\section{INTRODUCTION}

African swine fever (ASF) is a complex and lethal viral disease affecting domestic pigs and wild boar population, which also has a significant socioeconomic impact worldwide. It has a major negative effect on national, regional, and international trade in live pigs and pigs' meat (Gallardo et al., 2015a). The devastating acute form of the disease

${ }^{\star}$ Corresponding author. Email: simona.pileviciene@gmail.com is characterized by functional and congestivehaemorrhagic disorders of the digestive and respiratory systems. Case fatality rates may be as high as 100\% (Sánchez-Vizcaíno et al., 2015).

ASF is caused by a large DNA virus belonging to the family Asfarviridae (Dixon et al., 2005). The virus genome is 170 to $192 \mathrm{kbp}$ long (Chapman et al., 2011). ASF was first described in Kenya in the 1920s as an acute haemorrhagic fever, which at that time caused case fatality approaching $100 \%$ in domestic pigs. Disease outbreaks occurred when domestic pigs came 
into close contact with wildlife species, particularly warthogs (Phacochoerus aethiopicus and Phacochoerus africanus). The source of the infection was identified as a virus carried by warthogs, which did not show clinical disease (Montgomery, 1921). ASF has been confined mainly to sub-Saharan Africa, where it is maintained in a sylvatic cycle and among domestic pigs (Costard et al., 2009). Historically, ASF outbreaks were reported in Afri$\mathrm{ca}$, and parts of Europe, South America and the Caribbean. Since 2007, ASF has been reported in many countries across Africa, Asia, and Europe (OIE 2020). On 24 January 2014, two cases of ASF in wild boars were found in Lithuania and later in wild boars in Latvia, Estonia, and part of Poland bordering on Belarus (Gallardo et al., 2014; Pejsak et al., 2014a; Pejsak et al., 2014b). ASF spread further in Moldova, the Czech Republic, and Romania in 2017, in Hungary, China, Belgium, and Mongolia in 2018, and further to South East Asia (Mazloum et al., 2019). Since no vaccine is available against ASF, the only way to control and eradicate the disease and the spread of the virus is based on classical disease control methods, such as surveillance, rapid detection and identification of ASF virus-specific antigens or DNA and antibodies, and stamping out of infected animals (OIE, 2012, GavierWiden et al., 2015). To detect ASF antibodies, ELISA (enzyme-linked immunosorbent assay), indirect immunoflourescence (IIF), or the indirect immunoperoxidase test (IPT) are recommended (Gallardo et al., 2015; CISA INIA, 2019). For ASF virus genome detection by PCR, several methods can also be used, for example, OIE conventional PCR (Agüero et al., 2003), OIE real-time PCR (King et al., 2003), Universal Probe Library (UPL) realtime PCR (Fernández-Pinero et al., 2013), and duplex real-time PCR (Haines et al., 2013). Moreover, there are commercial kits for ASF detection - 'virotype ASFV PCR kit' (Qiagen), 'ID-Gene ${ }^{\mathrm{ta}}$ African Swine fever Duplex' (IDVet), and others.

Regarding the selected appropriate primers and the probe, reaction buffers and an- nealing temperature, the goal was to optimize ASF duplex assay in our laboratory. Based on research conducted by Haines et al. (2013) into simultaneous detection of ASF and IC, that allows proper detection of the ASF virus and internal control in one reaction tube and a comparison of singleplex (250bp fragment) and duplex (75bp fragment) real-time PCR assays for ASF virus detection using different primers, probes, and master mix. There is an important and urgent need to develop new and rapid molecular assays for the diagnosis of ASF with high sensitivity and specificity.

\section{MATERIALS AND METHODS}

Samples. Reference samples (INIA, Spain) and ASF virus positive and negative field samples of blood (EDTA stabilized and serum), kidney, spleen, muscle, lungs, bone marrow, and heart collected in 2014-2015 from domestic pigs and wild boars from affected areas in Lithuania were used for this study. Reference samples of Koi herpesvirus, avian influenza virus, and classical swine fever were used to evaluate analytical specificity of duplex ASFIC real-time PCR assay.

DNA extraction and real-time PCR. Total DNA was extracted from $140 \mu \mathrm{L}$ of a wide range of samples: blood-EDTA and serum using a Viral RNA Extraction Kit (Qiagen, Germany) and homogenized tissue using a RNeasy Mini Kit (Qiagen, Germany), following the manufacturer's procedure. The final elution was done with $80-125 \mu \mathrm{L}$ elution buffer. Extracted DNA was stored at $-20^{\circ} \mathrm{C}$ for further analysis. Field and reference samples were tested to detect the ASF virus genome using the primer and probe sequences summarized in Table 1.

Luminaris Probe High ROX qPCR Master Mix (2x) (Thermo Fisher Scientific), Maxima Probe/ROX qPCR Master Mix (2X) (Thermo Fisher Scientific) modified with UNG and Quantitect Multiplex PCR kit (Qiagen, Germany) were used for study. The reaction mix contained $5 \mu \mathrm{L}$ of extracted DNA and $12.5 \mu \mathrm{L}$ $2 \mathrm{x}$ reaction buffer, primers and probe for target 
Table 1. Primer and probe system used in singleplex and duplex real-time PCR assays

\begin{tabular}{|c|c|c|}
\hline Primer/Probe & Sequence & Reference \\
\hline \multicolumn{3}{|c|}{ Singleplex detection } \\
\hline \multicolumn{2}{|r|}{ ASF } & \multirow{4}{*}{ (King et al., 2003) } \\
\hline King's F & 5'-CTG CTC ATG GTA TCA ATC TTA TCG A-3' & \\
\hline Kings's R & 5'AGT ACC ACA AGA TCR GCC GT - 3' & \\
\hline ASF Probe 250 & $\begin{array}{l}\text { 5'AM-CCA CGG GAG GAA TAC CAA CCC AGT } \\
\text { G-TAMRA-3' }\end{array}$ & \\
\hline \multicolumn{2}{|r|}{ Internal control (IC) } & \multirow{4}{*}{ (Agüero et al., 2003) } \\
\hline IC2AI-F & 5'-TCG AGG GCG ACA CCC TG-3' & \\
\hline EGFP-R & 5'-CTT GTA CAG CTC GTC CAT GC-3' & \\
\hline EGFP-probe & $\begin{array}{l}\text { 5'VIC-AGC ACC CAG TCC GCC CTG AGC- } \\
\text { MGB-3' }\end{array}$ & \\
\hline \multicolumn{2}{|r|}{ Duplex detection } & \multirow{8}{*}{ (Haines et al., 2013) } \\
\hline & ASF & \\
\hline ASFVp72-IVI F & 5'-GAT GAT GAT TAC CTT YGC TTT GAA-3' & \\
\hline ASFVp72-IVI R & 5'-TCT CTT GCT CTR GAT ACR TTA ATA TGA-3' & \\
\hline ASFV probe & $\begin{array}{l}\text { 5'-FAM-CCA CGG GAG GAA TAC CAA CCC AGT } \\
\text { G-TAMRA-3' }\end{array}$ & \\
\hline \multicolumn{2}{|r|}{ Internal control (IC) } & \\
\hline EGFP1-F & 5'-GAC CAC TAC CAG CAG AAC AC-3' & \\
\hline EGFP2-R & 5'-GAA CTC CAG CAG GAC CAT G-3' & \\
\hline
\end{tabular}

and internal control. Primers ASF King F and ASF King $\mathrm{R}$ at concentration of $400 \mathrm{nM}$ and probe 250 at concentration of $100 \mathrm{nM}$ were used for singleplex real-time PCR. Concentration of primers and probe for ASF in duplex real-time PCR was optimized in final reaction volume of $25 \mu \mathrm{L}$ to obtain minimal threshold cycle. Concentration of primers and probe for duplex internal control was optimised from $100 \mathrm{nM}$. Concentration of primers and probe for duplex ASF-IC real-time PCR was optimized to obtain maximum sensitivity for target and internal control in the same reaction (Tables 2, 3). Real-time PCR reaction was carried out using 96-well plates by Applied Biosystems real-time PCR system. Samples

Table 2. Optimization of ASF duplex primer concentration. Ct value at different primer concentrations

\begin{tabular}{c|cc|c|c|c}
\hline \multirow{2}{*}{$\begin{array}{c}\text { ASF primer con- } \\
\text { centration, } \mathrm{nM}\end{array}$} & Session 1 & Session 2 & Session 3 & \multirow{2}{*}{ Average } & $\begin{array}{c}\text { Standard } \\
\text { deviation }\end{array}$ \\
\cline { 2 - 4 } & $29.1 \pm 0.3$ & $28.6 \pm 0.05$ & $28.6 \pm 0.07$ & 28.8 & 0.3 \\
\hline 900 & $28.7 \pm 0.07$ & $28.8 \pm 0.1$ & $28.7 \pm 0.06$ & 28.7 & 0.09 \\
\hline 800 & $29.2 \pm 0.3$ & $29.0 \pm 0.2$ & $28.8 \pm 0.06$ & 29.0 & 0.27 \\
\hline 700 & $29.5 \pm 0.04$ & $29.1 \pm 0.2$ & $28.9 \pm 0.1$ & 29.1 & 0.28 \\
\hline 600 & & & & \\
\hline
\end{tabular}


Table 3. Optimization of ASF duplex probe concentration. Ct value at different probe concentrations

\begin{tabular}{|c|c|c|c|c|c|}
\hline \multirow{2}{*}{$\begin{array}{l}\text { Probe concent- } \\
\text { ration, } \mathrm{nM}\end{array}$} & \multicolumn{3}{|c|}{$\mathrm{Ct}$} & \multirow{2}{*}{ Average } & \multirow{2}{*}{$\begin{array}{l}\text { Standard } \\
\text { deviation }\end{array}$} \\
\hline & Session 1 & Session 2 & Session 3 & & \\
\hline 100 & $28.9 \pm 0.2$ & $29.6 \pm 0.09$ & $29.6 \pm 0.2$ & 29.3 & 0.3 \\
\hline 200 & $28.5 \pm 0.07$ & $29.4 \pm 0.1$ & $29.4 \pm 0.07$ & 29.1 & 0.4 \\
\hline 300 & $28.4 \pm 0.06$ & $29.2 \pm 0.2$ & $29.5 \pm 0.1$ & 29.0 & 0.5 \\
\hline 400 & $28.4 \pm 0.04$ & $28.8 \pm 0.2$ & $29.2 \pm 0.3$ & 28.8 & 0.4 \\
\hline
\end{tabular}

were amplified using the following conditions: $2 \mathrm{~min}$ at $50^{\circ} \mathrm{C}, 10 \mathrm{~min}$ at $95^{\circ} \mathrm{C}$, followed by 40 cycles at $95^{\circ} \mathrm{C}$ for $15 \mathrm{~s}$ and at $60^{\circ} \mathrm{C}$ (singleplex ASF assay) for 1 min. Duplex ASF-IC realtime PCR annealing and extension temperature $\left(58-63^{\circ} \mathrm{C}\right)$ was optimised. Repetitiveness of the method was assessed using diluted reference ASF samples by repeating three times on different days. Data analysis was performed by following criteria: if a fluorescent signal is lower than a value of $38 \mathrm{ct}$ then the samples would be proved as positive, and if a fluorescent signal is equal to $38 \mathrm{ct}$ or higher, then these samples are repeated several times for confirmation.

Statistical analysis. The measured variables were tested for normality using the Kolmogorov-Smirnov test, and the hypotheses on data normality were not accepted. Therefore, the nonparametric Mann-Whitney $U$ test was used. For all hypotheses, statistically significant differences were accepted at a significance level of $P=0.10$ (Forthofer et al., 2007; CuadraSánchez et al., 2012).

\section{RESULTS}

Optimization of concentration of ASF primers and probe thermo-cycling conditions and buffers for duplex ASF-IC real-time PCR. Regarding the selected appropriate primers and probe, reaction buffers and annealing temperature, the goal was to develop a duplex real-time PCR assay for ASF and IC simultaneous detection that allows the proper detection of ASF virus and internal control in one reaction tube which does not affect the sensitivity of the method.
For optimization of ASF duplex primer concentration, was selected to perform the tests using primer concentration 600-900 nM (Haines et al., 2013). Diluted reference ASF samples were used for the tests (Table 2).

The lowest Ct value was obtained at $800 \mathrm{nM}$ ASF primer concentration. Also, using this concentration of primers, the standard deviation between tests was the lowest expecting the most repetitive results. Statistical analysis of primer concentration was performed using the nonparametric Mann-Whitney U test. Almost all measurements of different high concentrations of primers showed statistically significantly differences at a significance level of $P=0.10$.

ASF probe concentration for duplex study varied from $100 \mathrm{nM}$ to $400 \mathrm{nM}$ (Table 3).

By using the nonparametric Mann-Whitney $\mathrm{U}$ test for low concentrations, clearly defined tendencies were not observed. Differences between probe concentrations were altered without any consistent pattern. Studies with different combinations of probe concentration for the detection of the ASF virus determined that probe concentration had no influence on the results. The lowest selected probe concentration was $100 \mathrm{nM}$.

Similar studies were carried out for internal control using different (100-300 nM) primer and probe concentrations, and the data showed that there were no influences on results. The selected concentration was $100 \mathrm{nM}$ (data not shown).

The primer melting temperature for DNA matrices can be calculated using two methods: according to the formula $\mathrm{Tm}=2$ $(\mathrm{A}+\mathrm{T})+4(\mathrm{G}+\mathrm{C})$ (Von Ahsen et al., 2001), or 
by using the Thermo Fisher online calculator (Thermo Fisher Scientific). Comparing the results with different temperatures in all three sessions showed that clearly defined tendencies were not observed (Table 4).

Therefore we can state that the analysis of temperature changes based on the nonparametric Mann-Whitney U test did not result in significant outcomes. After the experiment of the optimisation of primer annealing tempera- ture, the optimal primer annealing temperature of $62^{\circ} \mathrm{C}$ was selected only by the assessment of the profile of the amplification curves.

Three different reaction buffers for singleplex and two different reaction buffers for duplex real-time PCR were used for ASF virus amplification from positive samples with primers listed in Table 1. Summary data in the Box and Whisker Plot are presented in Figure.

Table 4. Optimization of primer annealing temperature. Ct value at different primer annealing temperatures

\begin{tabular}{c|c|c|c|c|c}
\hline \multirow{2}{*}{ Temperature, ${ }^{\circ} \mathrm{C}$} & \multicolumn{3}{|c|}{$\mathrm{Ct}$} & \multirow{2}{*}{ Average } & $\begin{array}{c}\text { Standard } \\
\text { deviation }\end{array}$ \\
\cline { 2 - 4 } & Session 1 & Session 2 & Session 3 & & 0.3 \\
\hline 58 & $29.4 \pm 0.1$ & $28.9 \pm 0.3$ & $28.9 \pm 0.2$ & 29.1 & 0.2 \\
\hline 59 & $28.9 \pm 0.2$ & $28.6 \pm 0.2$ & $28.7 \pm 0.1$ & 28.8 & 0.2 \\
\hline 60 & $28.8 \pm 0.1$ & $28.7 \pm 0.2$ & $28.5 \pm 0.2$ & 28.6 & 0.2 \\
\hline 61 & $28.6 \pm 0.07$ & $28.4 \pm 0.1$ & $28.3 \pm 0.3$ & 28.5 & 0.1 \\
\hline 62 & $28.6 \pm 0.1$ & $28.3 \pm 0.2$ & $28.2 \pm 0.1$ & 28.4 & 0.2 \\
\hline 63 & $28.8 \pm 0.2$ & $28.7 \pm 0.2$ & $28.7 \pm 0.1$ & 28.7 & \\
\hline
\end{tabular}

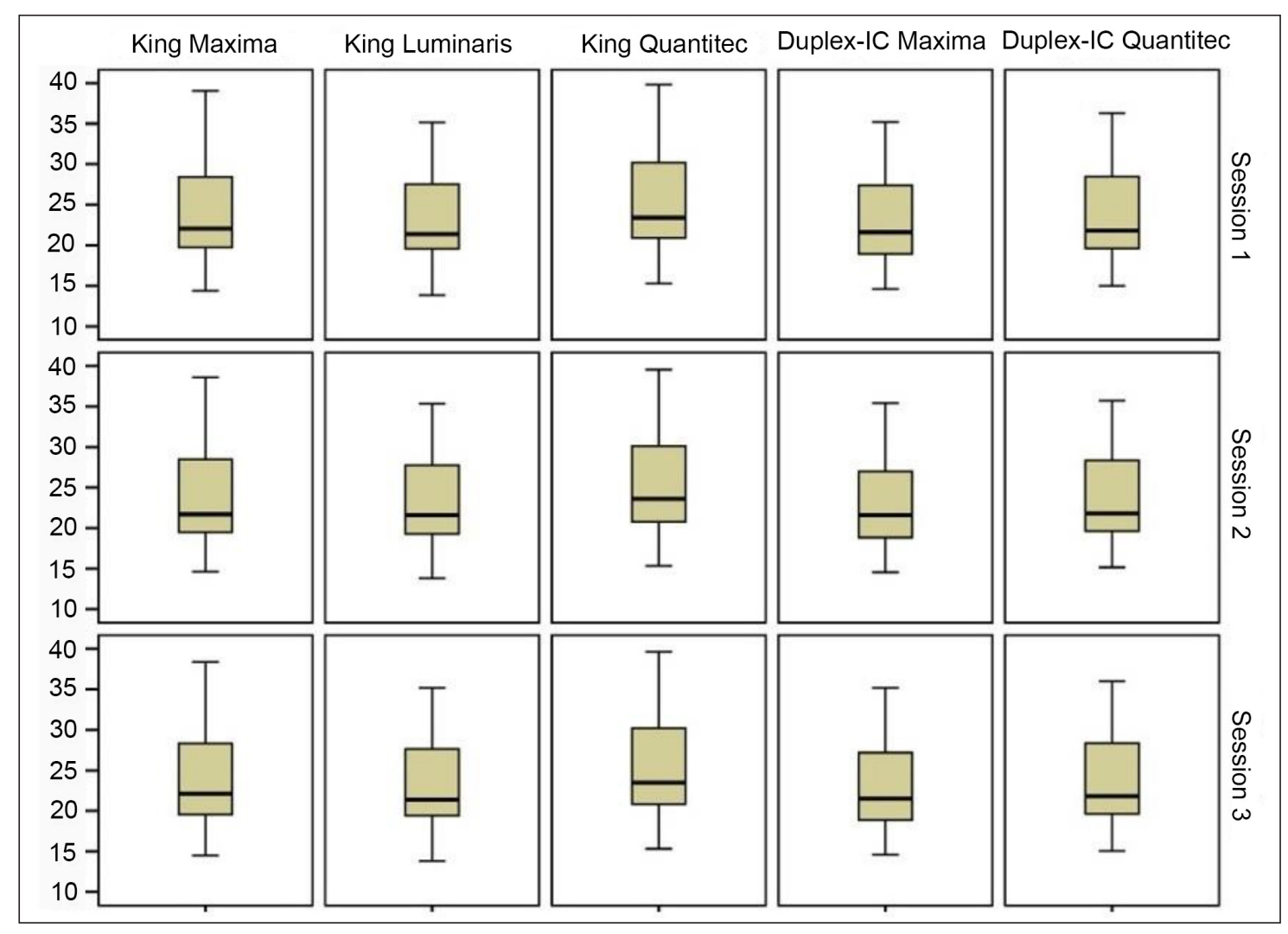

Figure. Real-time PCR results depending on ASF primers, buffers, and different real-time PCR sessions 
Statistically significant differences in all three sessions were observed at a significance level of $P=0.10$ using ASF King Quantitect Multiplex PCR kit (Qiagen) vs. Duplex ASFIC Maxima Probe/ROX qPCR Master Mix (2X) (Thermo Fisher Scientific). In all other cases there were no significant differences $(P>0.10)$. Study results confirmed that the reaction is more efficient if synthesized fragments are shorter. Shorter fragments were denatured effectively in each reaction cycle.

Buffers Maxima Probe/ROX qPCR Master Mix (2X) (Thermo Fisher Scientific) and Quantitect Multiplex PCR Master Mix kit (Qiagen, Germany) were selected for further tests. Using these buffers, the synthesized ASF virus DNA fragment determined lower Ct values. These cases were observed to have statistically significant differences. Non-specific amplification curves were obtained from duplex assays with buffer Luminaris Probe High ROX qPCR Master Mix (2X).

Analytical specificity. The nucleic acid extracted from positive ASF reference samples, positive reference samples of Koi herpes virus (KHV), Avian influenza virus (AIV), and classical swine fever virus (CSF) were used to evaluate analytical specificity of duplex ASF-IC real-time PCR assay. ASF reference samples were all positive. The nucleic acid from the reference samples of Koi herpes virus, Avian influenza virus, and classical swine fever were all negative. Results and Ct values are presented in Table 5.

Comparison of singleplex and duplex assay. For confirmation of validated duplex realtime PCR assay, ASF virus positive samples were tested in duplex ASF-IC real-time PCR and ASF real-time PCR (without IC) using Maxima Probe/ROX qPCR Master Mix (2X) (Thermo Fisher Scientific) (Table 6).

The nonparametric Mann-Whitney U test showed that there were no statistically significant differences between measurements of strongly positive samples for ASF real-time PCR and duplex ASF-IC real-time PCR with $P$-value, $P=0.10$.

Duplex ASF-IC real-time PCR is more sensitive and faster than singleplex ASF real-time PCR in detection of the ASF virus in blood, bone marrow, heart, kidney, liver, spleen, lungs, muscle, and meat products of domestic pigs and wild boars. Comparing singleplex real time PCR and duplex real-time PCR results, the difference in $\mathrm{Ct}$ value is $0.55-8.4$, which means that $0.3-70.5$ times more of the reaction product is synthesized. The internal control for ASF was detected in negative samples; this confirms the absence of inhibition in the sample. The ASF virus and the internal control were detected in one tube.

Table 5. Analytical specificity for duplex AS-IC real-time PCR assay. Average of the crossing point (threshold cycle) for duplex ASF-IC real-time PCR using different master mixes

\begin{tabular}{ccc}
\hline \multirow{2}{*}{ Samples } & \multicolumn{2}{c}{ Ct value of real-time PCR } \\
\cline { 2 - 3 } & $\begin{array}{c}\text { Maxima }^{\text {TM }} \begin{array}{c}\text { Probe qPCR Master } \\
\text { Mix }\end{array} \\
\text { QSF PC 17 }\end{array}$ & Quantitect Multiplex Master Mix \\
\hline ASF PC 19 & 28.8 & 29.9 \\
\hline ASF PC 29 & 23.5 & 26.7 \\
\hline KHV PC & not detected & not detected \\
\hline AIV PC & not detected & not detected \\
\hline CSF PC & not detected
\end{tabular}


Table 6. Sample analysis with singleplex and duplex real-time PCR. Comparison of clinical sample detection using duplex ASF-IC and singleplex ASF analysis

\begin{tabular}{|c|c|c|c|c|c|c|c|}
\hline \multirow{2}{*}{$\begin{array}{l}\text { Type of } \\
\text { sample }\end{array}$} & \multirow{2}{*}{$\begin{array}{l}\text { Singleplex } \\
\text { ASF Real- } \\
\text { time PCR } \\
\text { ASF Ct }\end{array}$} & \multicolumn{2}{|c|}{$\begin{array}{c}\text { Duplex ASF-IC Real- } \\
\text { time PCR }\end{array}$} & \multirow{2}{*}{$\begin{array}{l}\text { Type of } \\
\text { sample }\end{array}$} & \multirow{2}{*}{$\begin{array}{c}\text { Singleplex } \\
\text { ASF Real- } \\
\text { time PCR } \\
\text { ASF Ct }\end{array}$} & \multicolumn{2}{|c|}{$\begin{array}{c}\text { Duplex ASF-IC Real- } \\
\text { time PCR }\end{array}$} \\
\hline & & $\mathrm{ASF} C \mathrm{t}$ & $\mathrm{IC} \mathrm{Ct}$ & & & $\mathrm{ASF} C \mathrm{t}$ & IC Ct \\
\hline \multirow{12}{*}{ Blood } & 22.3 & 21.8 & 28.9 & \multirow{5}{*}{ Lungs } & 20.5 & 21.5 & 32.8 \\
\hline & 24.3 & 18.8 & No Ct & & 24.8 & 25.5 & 27.5 \\
\hline & 31.4 & 28.4 & 27.6 & & 20.4 & 21.7 & 28.9 \\
\hline & 27.3 & 24.9 & 27.5 & & 21.5 & 22.5 & 27.7 \\
\hline & 21.6 & 21.5 & 28.4 & & 24.7 & 25.5 & 27.2 \\
\hline & 24.5 & 19.6 & Not detected & \multirow{3}{*}{$\begin{array}{l}\text { Lungs/ } \\
\text { spleen }\end{array}$} & 24.2 & 23.9 & 27.5 \\
\hline & 34.3 & 30.6 & 27.5 & & 20.4 & 19.9 & 32.1 \\
\hline & 38.1 & 35.4 & 27.5 & & 21.2 & 18.7 & Not detected \\
\hline & 30.2 & 25.8 & 28.5 & \multirow{3}{*}{$\begin{array}{c}\text { Meat } \\
\text { product }\end{array}$} & Not detected & 31.6 & 30.8 \\
\hline & 15.3 & 15.1 & $\begin{array}{c}\text { Not detected } \\
\text { no Ct }\end{array}$ & & Not detected & 34.5 & 29.9 \\
\hline & 26.5 & 25.4 & 28 & & 30.6 & 28.1 & 27.7 \\
\hline & 19.8 & 20.1 & Not detected & \multirow{3}{*}{ Muscle } & 36.8 & 36.0 & 27.6 \\
\hline \multirow{3}{*}{$\begin{array}{l}\text { Bone } \\
\text { marrow }\end{array}$} & 29.6 & 28.4 & 27.6 & & 34.4 & 33.1 & 28.9 \\
\hline & 33.6 & 31.5 & 27.9 & & 39.7 & 33.5 & 29.8 \\
\hline & 24.4 & 23.4 & 27.6 & \multirow{22}{*}{ Spleen } & 19.5 & 18.5 & Not detected \\
\hline \multirow{5}{*}{ Heart } & 27.6 & 28.4 & 26.9 & & 30.5 & 28.9 & 27.5 \\
\hline & 32.5 & 32.7 & 27.6 & & 18.5 & 17.8 & Not detected \\
\hline & 25.2 & 26.4 & 27.8 & & 19.4 & 18.7 & Not detected \\
\hline & 24.2 & 25.4 & 27.5 & & 26.9 & 25.6 & 27.4 \\
\hline & 32.5 & 33.2 & 27.9 & & 23.5 & 22.3 & 28 \\
\hline \multirow{7}{*}{ Kidney } & 26.6 & 25.6 & 27.2 & & 17.7 & 16.7 & Not detected \\
\hline & 20.7 & 19.9 & 31.6 & & 21.3 & 20.7 & 29.8 \\
\hline & 21.2 & 21.9 & 27.1 & & 20.4 & 19.7 & 36.4 \\
\hline & 26.4 & 27.7 & 27.2 & & 20.8 & 20.7 & 31.1 \\
\hline & 25.9 & 26.6 & 27.2 & & 35.3 & 33.1 & 28.1 \\
\hline & 24.4 & 25.4 & 27.7 & & 21.7 & 21.5 & 30.4 \\
\hline & 34.9 & 35.0 & 28.2 & & 18.2 & 17.5 & Not detected \\
\hline \multirow{8}{*}{ Liver } & 18.9 & 16.9 & Not detected & & 22.6 & 21.8 & 28.5 \\
\hline & 35.6 & 32.5 & 27.5 & & 22.4 & 21 & 35.3 \\
\hline & 22.1 & 19.1 & Not detected & & 18.6 & 16.6 & Not detected \\
\hline & 20.9 & 21.7 & 27.5 & & 20.8 & 20.1 & 34.2 \\
\hline & 18.4 & 19.8 & Not detected & & 17.8 & 18.9 & Not detected \\
\hline & 22.5 & 23.5 & 29.1 & & 20.2 & 21.5 & 28.7 \\
\hline & 20.69 & 21.6 & 33.5 & & 18.3 & 19.7 & Not detected \\
\hline & 22.3 & 22.8 & 28.2 & & 21.7 & 22.7 & 27.6 \\
\hline \multirow{2}{*}{ Tissue } & 23.2 & 21.6 & 30.8 & & 22.7 & 23.4 & 27.4 \\
\hline & 25.6 & 24.5 & 27.6 & & & & \\
\hline
\end{tabular}




\section{DISCUSSION}

ASF has emerged in several European countries (EFSA, 2020). Since it is complicated to control the Asian wild boar population and its movements, ASF is progressively spreading among the animals in this area (Guberti et al., 2019; FAO, 2020). Although large pig farms are better protected by biosecurity, ASF-infected wild boars contaminating the environment pose a threat (Gavier-Widen et al., 2015). The real-time PCR is the main diagnostic tool when the viral isolates are lethal to animals. However, due to the presence of strains of reduced virulence that result in lower mortality, the ASF disease can be diagnosed by using serological tests (Gallardo et al., 2015b). Laboratory testing of wild boars and domestic pigs is essential for active and passive surveillance and prevention of new ASF outbreaks and implementation of effective control programmess (Guinat et al., 2017). Both singleplex and duplex real-time PCR assays enable detection of the ASF virus and can be used as more sensitive test methods for the detection of the ASF virus (King et al., 2003; Haines et al., 2013). Therefore, a specific duplex (simultaneous detection of ASF and IC) real-time PCR assay was analysed using different real-time PCR Master Mix: Luminaris Probe High ROX qPCR Master Mix (Thermo Fisher Scientific), Maxima Probe/ROX qPCR Master Mix (2X) (Thermo Fisher Scientific), and Quantitect Multiplex PCR kit (Qiagen, Germany). Specific primers and the probe used resulted in amplifying a 250-bp region and 75-bp region of the p72 gene. Amplification results demonstrated that the duplex real-time PCR assay is able to reliably detect sensitivity and is much quicker when the most suitable means are used: Master Mix which is Maxima Probe/ROX qPCR Master Mix (2X) (Thermo Fisher Scientific) and Quantitect Multiplex PCR kit (Qiagen, Germany). However, duplex ASF-IC real-time PCR assay optimization of primers, probe concentrations, and annealing temperature ensures optimal efficiency in real-time PCRs. For the detec- tion of the ASF virus, the optimal primer concentration for duplex ASF is $800 \mathrm{nM}$ and optimal probe concentration was $100 \mathrm{nM}$ while the optimal primer annealing temperature was observed to be $62^{\circ} \mathrm{C}$. The study was carried out using different primer concentrations for internal control. Study results showed that concentration of primer for internal control did not influence the detection of ASF virus. Real-time PCR assay parameters were optimized; the efficiency of the real-time PCR was highly sensitive to the incidence of PCR inhibitors, which are sometimes present in DNA extracts, depending on the type of product to be analysed, including blood, bone marrow, heart, kidney, liver, spleen, lungs, muscle, and meat products. The results show that for the detection of the ASF virus, the highest Ct value was recorded in meat products and muscle, while in all other organs and tissues it was comparable, but differences were observed between singleplex and duplex realtime assays detection. Duplex real-time PCR assay is more sensitive to the Ct value margin, which varies from $0.5 \mathrm{Ct}$ to almost $8.5 \mathrm{Ct}$. If the sample is strongly positive for ASFV DNA, the difference is negligible, and if the sample is weakly positive then the differences between singleplex and duplex real-time PCR assays are more significant.

\section{CONCLUSIONS}

Duplex real-time PCR can complement the current methods that are used for the detection of the ASF virus. Duplex ASF-IC realtime PCR assay proved to be specific, more sensitive, and replicable. This makes the method particularly useful for the early stage of ASF virus infection or for testing the disintegrated samples in the shortest possible time. Duplex ASF-IC real-time PCR assay offers the possibility to save time and reduce the costs of analysis, and therefore has a high potential for application in routine analysis.

Received 13 January 2020 Accepted 14 February 2020 


\section{References}

1. Agüero M, Fernández J, Romero L, Sánchez Mascaraque C, Arias M, Sánchez-Vizcaíno JM. Highly sensitive PCR assay for routine diagnosis of African swine fever virus in clinical samples. J Clin Microbiol. 2003; 41: 4431-4.

2. Chapman DA, Darby AC, Da Silva M, Upton C, Radford AD, Dixon LK. Genomic analysis of highly virulent Georgia 2007/1 isolate of African swine fever virus. Emerg Infect Dis. 2011; 17(4): 599-605.

3. CISA-INIA. asf-referencelab.info [Internet] African swine fever (ASF) Antibody detection [cited 2019 Dec 18] Available from: https:// asf-referencelab.info/asf/en/procedures-diagnosis/diagnostic-procedures

4. Costard S, Wieland B, Glanville W, Jori F, Rowlands R, Vosloo W, Roger F, Pfeiffer DU, Dixon LK. African swine fever: how can global spread be prevented? Phil Trans R Soc B. 2009; 364: 2683-96.

5. Cuadra-Sánchez A, Aracil J. Comparative analysis of traffic anomaly detection methods. In: Mellouk A, editor. Traffic anomaly detection. London: Elsevier Ltd; 2015. p. 29-45.

6. Dixon LK, Escribano JM, Martins C, Rock DL, Salas ML, Wilkinson PJ. Asfarviridae In: Fauquet CM, Mayo MA, Maniloff J, Desselberger U, Ball LA, editors, Virus taxonomy: VIIIth report of the International Committee on Taxonomy of Viruses. London: Academic Press; 2005. p. 135-43.

7. EFSA (European Food Safety Authority), Miteva A, Papanikolaou A, Gogin A, Boklund A, Bøtner A, Linden A, Viltrop A, Schmidt CG, Ivanciu C, Desmecht D, Korytarova D, Olsevskis E, Helyes G, Wozniakowski G, Thulke H-H, Roberts H, Abrahantes JC, Stahl K, Depner K, Gonzalez Villeta LC, Spiridon M, Ostojic S, More S, Vasile TC, Grigaliuniene V, Guberti V and Wallo R. Scientific report on the epidemiological analyses of African swine fever in the European Union (November 2018 to October 2019). EFSA J. 2020; 18(1): 5996, 107 p.

8. fao.org [Internet] ASF situation in Asia update [cited 2020 Feb 06] Available from: http://www.fao.org/ag/againfo/programmes/ en/empres/ASF/situation_update.html

9. Fernández-Pinero J, Gallardo C, Elizalde M, Robles A, Gómez C, Bishop R, et al. Molecular diagnosis of African swine fever by a new real-time PCR using universal probe library. Transbound Emerg Dis. 2013; 60(1): 48-58.

10. Forthofer RN, Lee ES, Hernandez M. MannWhitney U Test. In: Biostatistics (2nd ed.). London: Elsevier Academic Press; 2007.

11. Gallardo C, Fernández-Pinero J, Pelayo V, Gazaev I, Markowska-Daniel I, Pridotkas G, Nieto R, Fernández-Pacheco $\mathrm{P}$, Bokhan S, Nevolko O, Drozhzhe Z, Pérez C, Soler A, Kolvasov D, Arias M. Genetic variation among African swine fever genotype II viruses, Eastern and Central Europe. Emerg Infect Dis. 2014 ; 20(9): 1544-7.

12. Gallardo C, Torre Reoyo A, Fernández-Pinero J, Iglesias I, Muñoz MJ, Arias ML. African swine fever: a global view of the current challenge. Porc Health Manag. 2015a; 1: 21.

13. Gallardo C, Nieto R, Soler A, Pelayo V, Fernández-Pinero J, Markowska-Daniel I, Pridotkas G, Nurmoja I, Granta R, Simón A, Pérez C, Martín E, Fernández-Pacheco P, Arias M. Assessment of African swine fever diagnostic techniques as a response to the epidemic outbreaks in eastern European Union countries: how to improve surveillance and control programs. J Clin Microbiol. 2015b; 53(8): 2555-65.

14. Gavier-Widen D, Gortazar C, Stahl K, Neimanis S, Rossi S, Hard av Segerstad C, Kuiken T. African swine fever in wild boar in Europe: a notable challenge. Vet Rec. 2015; 176(8): 199-200.

15. Guberti V, Khomenko S, Masiulis M, Kerba S. African swine fever in wild boar ecology and 
biosecurity. FAO Animal Production and Health Manual. Rome: FAO, OIE and EC; 2019.

16. Guinat C, Vergne T, Jurado-Diaz C, SánchezVizcaíno JM, Dixon , Pfeiffer DU. Effectiveness and practicality of control strategies for African swine fever: what do we really know? Vet Rec. 2017; 180: 97.

17. Haines FJ, Hofmann MA, King DP, Drew TW Crooke HR. Development and validation of multiplex, real-time RT PCR assay for the simultaneous detection of classical and African swine fever viruses. PLOS ONE. 2013; 8(7): e71019.

18. King DP, Reid SM, Hutchings GH, Grierson SS, Wilkinson PJ, Dixon LK, Bastos AD, Drew TW. Development of a TaqMan PCR assay with internal amplification control for the detection of African swine fever virus. J Virol Methods. 2003; 107(1): 53-61.

19. Mazloum A, Igolkin AS, Vlasova NN, Romenskaya DV. African swine fever virus: use genetic markers in analysis of its routes of spread. Veterinary Science Today. 2019; 3(30): 3-8. Russian.

20. Montgomery RE. On a form of swine fever occurring in British East Africa. J Comp Pathol. 1921; 34: 59-191.

21. oie.int [Internet] Situational updates of ASF in Asia and the Pacific [cited 2020 Feb 11] Available from: https://rr-asia.oie.int/en/projects/asf/situational-updates-of-asf-in-asiaand-the-pacific/
22. Pejsak Z, Truszczyn'ski M, Niemczuk K, Kozak E, Markowska-Daniel I. Epidemiology of African swine fever in Poland since the detection of the first case. Pol J Vet Sci. 2014a; 17: 665-72.

23. Pejsak Z, Truszczyn'ski M, Kozak E, Markowska-Daniel I. Epidemiological analysis of two first cases of African swine fever in wild boars in Poland. Medycyna Weter. 2014b; 70: 369-72.

24. Sánchez-Vizcaíno JM, Mur L, Gomez-Villamandos JC, Carrasco L. An update on the epidemiology and pathology of African swine fever. J Comp Pathol. 2015; 152(1): 9-21.

25. Sur JH. How far can African swine fever spread? J Vet Sci. 2019; 20(4): e41.

26. Thermo Fisher Scientific. Tm calculator. https://www.thermofisher.com/lt/en/home/ brands/thermo-scientific/molecular-biology/ molecular-biology-learning-center/molecular-biology-resource-library/thermo-scientific-web-tools/tm-calculator.html

27. Von Ahsen N, Wittwer CT, Schutz E. Oligonucleotide melting temperatures under PCR conditions: nearest - neighbor corrections for $\mathrm{Mg} 2^{+}$deoxinucleotide triphosphate, and dimethyl sulfoxide concentrations with comparison to alternative empirical formulas. Clin Chem. 2001; 47: 1956-61.

28. World Organisation for Animal Health. African swine fever. In: OIE terrestrial manual 2012. World 2012. 
Simona Pilevičienè, Vaclovas Jurgelevičius, Žygimantas Janeliūnas, Gediminas Pridotkas, Petras Mačiulskis, Ričardas Krikštolaitis, Algimantas Paulauskas

SKIRTINGŲ AFRIKINIO KIAULIŲ MARO VIRUSO NUSTATYMO METODŲ IVERTINIMAS

\section{Santrauka}

Afrikinio kiaulių maro (AKM) suvaldymui iki šiol nèra jokios vakcinos ar gydymo, todèl ligos stebèjimas ir ankstyva diagnostika yra vienintelis būdas ją kontroliuoti. Labai svarbu yra įdiegti naujus ir greitus molekulinius AKM diagnozavimo metodus, pasižyminčius dideliu jautrumu ir specifiškumu. Šio tyrimo tikslas buvo parinkus tinkamus reakcijos pradmenis ir zondus, reakcijos buferius ir pradmenų prilydimo temperatūrą, optimizuoti daugybinès realaus laiko PGR metodą, kuriuo galima aptikti
AKM virusą ir užtikrinti vidinę kontrolę, bei palyginti AKM viengubos (250 bp AKM fragmentas) ir AKM-IC daugybinès (75 bp AKM fragmentas) realaus laiko PGR metodus. Buvo patvirtintas daugybinès realaus laiko PGR metodo specifiškumas ir jautrumas. Gauti rezultatai rodo, kad AKM-IC daugybinès realaus laiko PGR metodas yra greitesnis ir jautresnis nei realaus laiko PGR (juo nustatomas tik 250 bp AKM fragmentas) nustatant AKM virusą naminių kiaulių ir šernų kaulų čiulpų, širdies, inkstų, kepenų, blužnies, plaučiu, maisto produktų ir kt. mèginiuose. Po tyrimų Ct vertès pagal šiuos metodus skyrèsi per 0,55-8,4 ciklo, tai reiškia, kad daugybinès realaus laiko PGR metodu sintetinama 0,3-70,5 karto daugiau reakcijos produkto.

Raktažodžiai: afrikinio kiaulių maro viruso aptikimas, naminès kiaulès, daugybinè realaus laiko PGR, tikslinè realaus laiko PGR, šernai 